\title{
物体周りの組織渦を利用した浮遊砂の促進について \\ Promotion of Sediment Suspension Utilizing Coherent Vortices \\ around obstacle
}

田中規夫* 、金子哲也**

By Norio TANAKA and Tetsuya KANEKO

\begin{abstract}
The promotion of sediment suspension in a laboratory flume is discussed. Due to strong upward flow behind a spherical obstacle fixed at the bottom, bed materials are transported as suspended load. Horse-shoe vortices in front of the obstacle generate scour hole around it, and arch-shaped vortices behind the obstacle produce ripples in its near downstream area. Sand particles are entrained by the coherent vortices even after the scour hole has developed, which is detected by the distributions of suspended sediment. The obstacle placed in front of a weir can increase the amount of the suspended sediment passing over the weir.

Keywords: suspended load, coherent vortices, obstacle, weir
\end{abstract}

1.はじめに

河川に堰や床止めなどの横断工作物が作られると、その下流部においては給砂量が減少し、その結果、河 床の低下が生じ、お筋などの深掘れ部がひいては側岸侵食や堤防の決壊を生じさせることがある。また、 河口部においては河口砂州が形成され河口閉塞などの問題が生じることがある。

一般に、河川に粗度をつけることは洪水時の抵抗となり、蛇行部におけるべーン工などを除けばあまり好 まれない傾向にある。しかし、堰の前などに浮遊砂を促進するような構造物をつけておき、越流時に堰の前 面部にある砂を下流侧に押し流すことが出来れば、坆による給砂量の娍少はある程度防げるはずである。し かる、その浮遊砂促進工は堰による抵抗に比べるとそれはど流水を阻害するすのとはならない。

底面上の物体の後方には強い上昇流を持った組織渦が形成されることがわかっている11.21。従来、物体周 りの組織渦の研究は、流れの可視化による流況観察と条件付き点計测によりその組織渦の持つ情報が引き出 されてきつつあるが、その現象の複雑さが故に、それを工学的に応用した例は、河川の場合にはあまりみあ たらない。

そこで、本研究では、組織渦を利用した浮遊砂促進工の開発を考える。物体としては、平板に半球を取り 付けた物体周りの流れが、筆者らの研究により流れ場の特性が明らかになりつつあるので、砂の中に球を半

\footnotetext{
* 学生会員 工修 東京大学大学院工学系研究科土木工学専攻

** 学生会員東京大学工学部土木工学科学生

(宁113 文京区本郷 7-3-1)
} 
分埋めたような状热の物を考えることにする（形状の影響については、ここでは取り扱わないこととする）。 浮避砂を促進するといっても、物体の周りが洗掘され定常な状柋に達すると、もはやあまり浮遊砂を促進す る效果は期待できないと思われる。しかし、物体により作られた上昇流が流速分布や湛度分布を変化させる ので、定常になったあとも堰を越えていく砂の量を增やすことは期待できる。従って、ここでは洗掘される 領域を求めることと、洗掘後における流速分布ならびに濃度分布の変化を調べることにより、どの程度の容 積を下流に対して押し流せるものなのかを検討することにする。

\section{2 . 実験装置および実験方法}

実験には、全長 $20 \mathrm{~m} 、$ 幅 $40 \mathrm{~cm}$ 、高さ $50 \mathrm{~cm}$ の水路を使用した。実験は、まず上流から $10 \mathrm{~m}$ の地点に堰を設け、 その上流侧の水路床上に石炭粉（平均粒径 $0.18 \mathrm{~mm}$ 、比重 1.48 、限界摩擦速度 $0.91 \mathrm{~cm} / \mathrm{s}$ 、沈降速度 $0.85 \mathrm{~cm} / \mathrm{s}$ ) を厚さ $4 \mathrm{~cm}$ 程度に平坦に敷き詰めたのち、球を堰の上流地点に半分が埋まるような状態で沈設した（図ー1）。 実験に使用した球はスチール製で、半径が $1.0 \mathrm{~cm}, 1.5 \mathrm{~cm}, 2.0 \mathrm{~cm}$ の 3 種類を使用した。実験は下流侧を堰あげ た状態で行い、物体の上流、下流1地地点で水深Hを計測し、エネルギー勾配 $\mathrm{i}$ 、摩擦速度u・を求めた。

実験は 2 段階に分けて行われた。1つは、埋設された球がその周りにどの様な河床変化を引き起こすかと いうことを調べ、河床形状が充分定常になった後、その下流側にどのような濃度場、速度場を作り出すかと いう実験である（実験条件、表一 1 のRUN1〜RUN3、A 実験と呼ぶことにする。なお、表ー1で、U曰は接近流 の断面平均流速を表す。）。すう1つは、その球が堰の近くに付設されたときに殹を越える浮遊砂量をどの 程度変化させることができるかという実験であり、娾と物体の距離を変化させてその効果を検討した（RUN4 ,RUN5、B 実験と呼ぶことにする。）。A 実験の場合には、球と㘿の距離 $X_{R}$ を $4.0 \mathrm{~m}$ の位置（球の半径の 200 倍 から400倍）に設置し、堰前面部に生じる渦との干路がない状態で行った。また、B実験の場合には物体と殹 との距離 $X_{R}$ を変化させて、堰を越えていく流れとの干渉について調べた。なお、流速の测定にはプロペラ式 流速計を、濃度の测定には光学式濁度計を使用した。浮遊砂量は濃度分布と速度分布を掛け合わせて求めた あの以外に、サイフォンにより実際に抜き取って求め、比較検討を行った（サイフォンによる抜取り速度は 测定点の流速にほぼ合わせた。）。ここで、とくにこのB実験においては非定常過程において浮遊砂量がど の程度あり、また问床形状が安定した後もどの程度の巻き上げの効果があるものなのかを検討した。従って、 堰頂部において10分每に濃度分布と流速分布の同時測定を行った。ひとつの計测線を図る時間は3分30秒であ り、この間も河床形状は変化しているが、時間間隔よりは短く、その大体の傾向を抑えることはできるもの と思われる。流れ場は、流速を测定した以外に、染料による可視化とアルミ粉による断面視によりその概略 をとらえた。また、河床形状の測定は、通水を止めた後にポイントゲージにより行った。

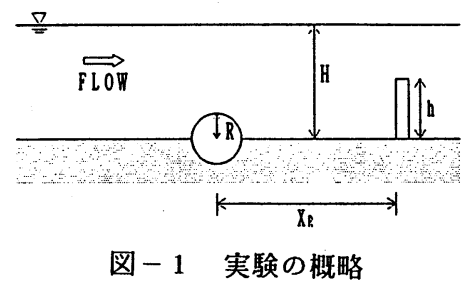

表 -1 実験条件

\begin{tabular}{|l|c|c|c|c|c|}
\hline & RUN1 & RUH2 & RUN3 & RUHA & RUN5 \\
\hline$U_{0}(\mathrm{~cm} / \mathrm{s})$ & 16.5 & 16.5 & 16.5 & 10.6 & 10.6 \\
i $(\mathrm{cm})$ & 10 & 10 & 10 & 8 & 8 \\
$\mathrm{i}_{0}$ & 0.0025 & 0.0025 & 0.0025 & 0.0029 & 0.0029 \\
$\mathrm{u} \cdot(\mathrm{cm} / \mathrm{s})$ & 1.12 & 1.12 & 1.12 & 1.51 & 1.51 \\
$\mathrm{R}(\mathrm{cm})$ & 1.0 & 1.5 & 2.0 & 2.0 & 2.0 \\
$X_{R}(\mathrm{~cm})$ & 100 & 100 & 100 & 10 & 20 \\
$\mathrm{~h} \quad(\mathrm{~cm})$ & 5.0 & 5.0 & 5.0 & 1.0 & 1.0 \\
\hline
\end{tabular}

3. 半球の周りの洗掘過程ならびに洗掘後の流速分布、濃度分布の特性について

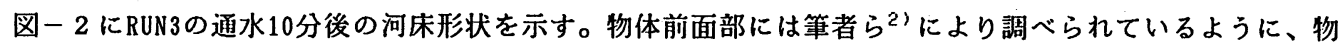
体を取り四む馬蹄形状の渦が形成される。円柱の場合と同様に3)、この渦が形成される領域は局所的に底面 せん断力が高く、物体に沿って局所的な深掘れが生じる(A)。この深掘机はほぼ左右対象に生じ、前面部で卷 き上げられた砂は物体の後方にほぼ左右対象に堆積する(B)。中央断面においては、再付着点より下流侧に、 
再付着点付近より持ち上げられた砂が堆積する(C)。（B)や (C)の河床波背後からは、剥離渦が放出され、周期的に砂を巻 き上げるのが観察される。そして、これらが引金となってそ の下流側に第 2 、第 3 の河床波が形成される。

通水後 1 時間す経過すると河床形状そのものはあまり目だ った変化はなくなり、物体回りの洗掘溝や河床波背後から巻 上がった砂が、物体や河床波によりつくられた㔀離渦により かなり下流まで持ち上げられて流下するのが確認される。

図一 3 (a)，(b)に通水後、1 時間経過したのちのRUN1, RUN3 の河床の等高線を示す（半径Rで無次元化）。いずれの場合も

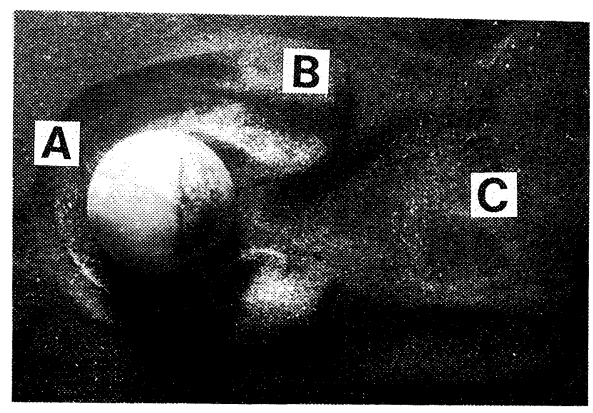

図-2 河床の変化 物体径の 2 倍程度の洗掘溝が形成され、物体の側方から後方 にかけて浅くなり、物体背後に堆積し、また、4R付近において左右対象に堆積した領域が確認される。 RUN1およびRUN3を比較すると形状がほぼ相似であることがわかる。ただし、流速や摩擦速度の変化や、粒 径の変化による沈降速度の変化により沈降する場所が变化し、下流部の起伏の形状については様々な場合が 起こりうると思われる。ここでは、この河床形状について議論するのではなく、粗度により河床変化を引き 起こすことそのものを重要ととらえる。すなわち、掃流状態にある砂を河床形状の変化により生じる剝離渦 により巻き上げ、浮遊砂に変換することが重要なのである。

定常後の流れを可視化した結果を図ー4 (a), (b)に示す。(a)は、前面および側方部の洗掘溝を回り込む流 れを染料により可視化したものであり、図中 A， Bで示したものが砂を巻き上げる馬蹄形渦ならびに物体背 後の剝離渦である。(b) は中央断面をアルミ粉により可視化したすのであり、物体後方の剝離渦 $\mathrm{B}$ をらえた ものである。

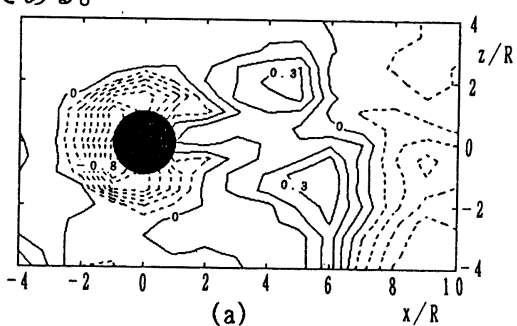

(a)

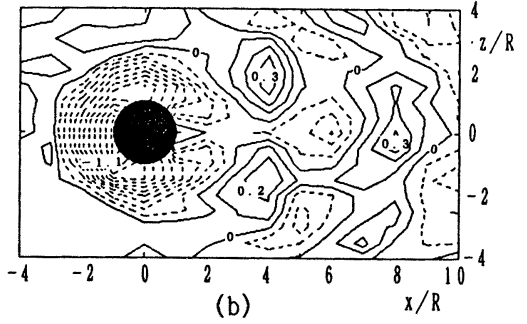

(b)

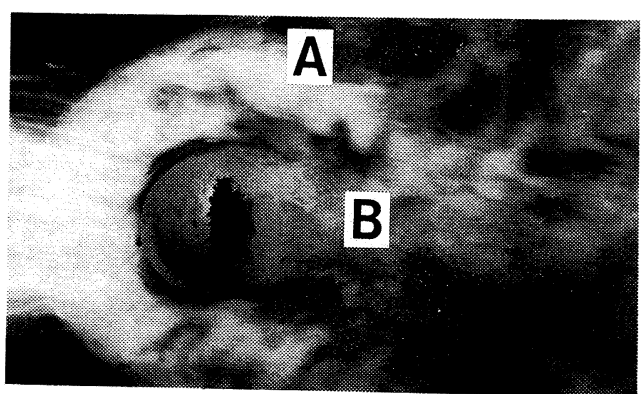

(a) 全体像

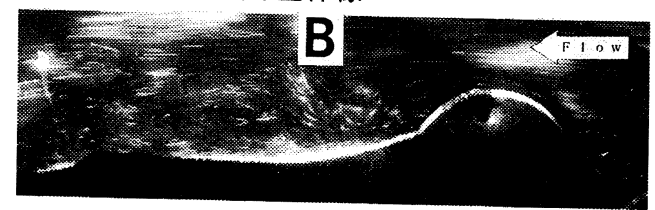

(b) 中央断面

図-3 河床の等高線（実線が隆起、点線が洗掘）

次に、RUN3における下流部の濃度(C)の分布並びに速度(u)の分布の計測結果、ならびにそれらを掛け合わ せて求めた浮遊砂量 $(\mathrm{q})$ の分布を図ー5 (a)〜 (c)に示す（ここで、濃度しは無次元の体積濃度を用いた。）。 (a)の濃度分布において、組織渦の通過する剝離領域内部に濃度分布のピークが見られるがそれらは流下方向 に微妙な変化をしているのがわかる。これらを可視化観察結果を考慮してまとめると、4R付近で底面付近の 濃度が高くなっているのは、物体前面部および側方部の洗掘溝から持ち上げられた砂の影響であり、8R付近 でその值が一端小さくなっているのは、その位置が河床の山の間にあり（図－3参照）、その両わきの断面 
に浮遊砂が逃げているためと思われる。しかし、12Rから20Rにかけては、河床波の背後にあたり濃度分布に

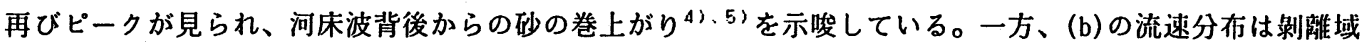
直後でかなり遅くなっているが流下するにしたがって回復しているのがわかる。従って、(c)のそれらを掛け 合わせた浮遊砂量の分布は㓦離渦の通過する高さ付近にピークのあることがわかる。そして、少なくとも20 $\mathrm{R}$ 付近までは浮遊砂量の分布は接近流の值よりも大きくなっており、この位置までは浮遊砂巻き上げの効果を 充分に期待できることがわかる。

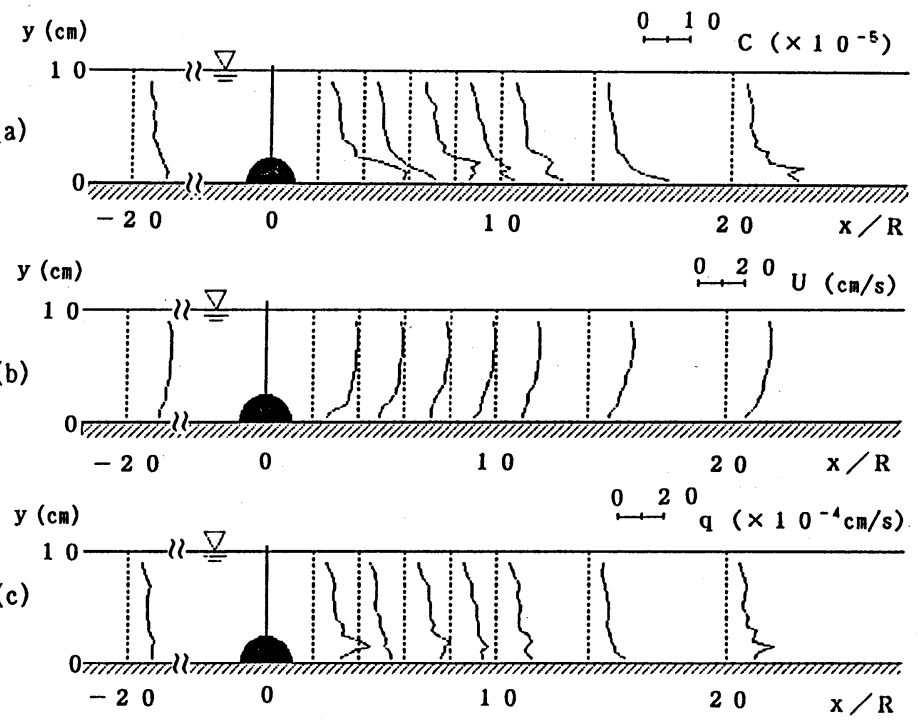

図- 5 物体下流の濃度C, 流速U, 浮遊砂量 $\mathrm{q}$ の分布（RUN3）

4. 堰前面部における浮遊砂の促進工としての効果について

3 の実験結果から物体を堰などの横断工作物の前におくと、堰の設置により止められてしまった掃流砂を 浮遊砂という形に変換して堰を越えさせることができるはずである。しかしながら、粗度自身が引き起こす 洗掘の影響で堰前面部が洗掘されるようではいけないし、かといって、粗度の影響により巻上がられた砂が 沈降してしまっては何にもならない。従って、物体高さと塊の高さとの比によって適した位置が存在するは ずである。

ここで、3より、20R付近までは、浮遊砂の巻き上げ促進の効果が期待できるので、堰の前面部にこの範围 で設置すれば、堰前面部の上昇流に乗って堰を越えることができるはずである。るちろん、坆前面部に物体 を設置することにより、物体後方の剶離流と堰前面部の渦が干渉して複雑な流れになるが、ここではその流 れ場そのものの変化は取り扱わず、実際に堰を越える浮遊砂量がどの程度增えるすのなのかということにつ いて検討することとする。

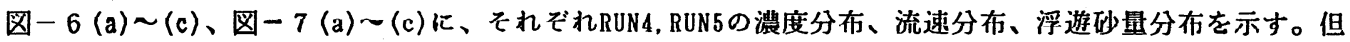
し、T0，T1，T3，T4，T5はそれぞれ通水後0、10、30、40、50分後の测定結果を表す。

RUN4, RUN5とも物体がない場合に比べて、流速分布が板の近くで遅くなり高速部がやや上方にずれるのが確 認される。これは、物体後方の䟝離渦により底面付近の低速流体が巻き上げられているためと思われる。

RUN4は物体と堰との距離が5R 比較的近い場合である。この場合は、図-3に示した河床形状の内、第 1 波までが形成される。従って、定常になる時間は比較的短く、浮遊砂として巻き上げられるのは、物体回引 の洗掘によるものである。すなわ方、図ー6 (a)，(c)の濃度分布、浮遊砂分布からもわかるように、T0, T1，T 3と增えていき、T4,T5になるとおちてくる。河床形状るこのときはほとんど变化せず、T5のときは定常にな ったと判断できる。また、浮遊砂量は定常時においても物体がないときに比べて非常に多いことがわかる。 
つまり、物体前面部まで掃流状態できたものが洗掘溝に取り込まれ、渦により巻き上げられ、浮遊砂に変換 されていると判断できる。一方、RUN5の場合は、物体と堰との距離が10Rの場合であり、図ー 3 の河床形状の 内、第 2 波までが形成される。従って、定常になるまでの時間はRUN4よりす長く、浮遊砂として巻き上げら れるのは、RUN4のものに加えて、物体背後の河床から巻き上げられるすのあ含まれる。すなわち、図 7 (a)，(c)の濃度分布、浮避砂分布からもわかるように測定した範囲内では、時間がたつにつれて上昇する。こ の結果、非定常時における輸送量を考えると、RUN4よりるRUN5の方が多く輸送できると思われる。

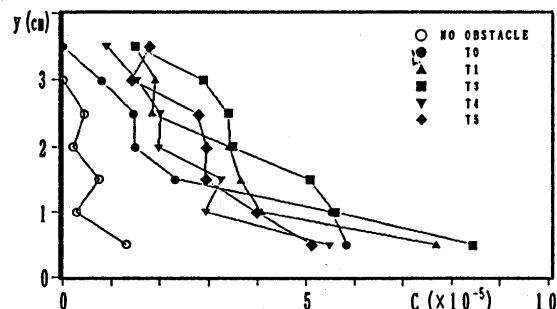

(a)

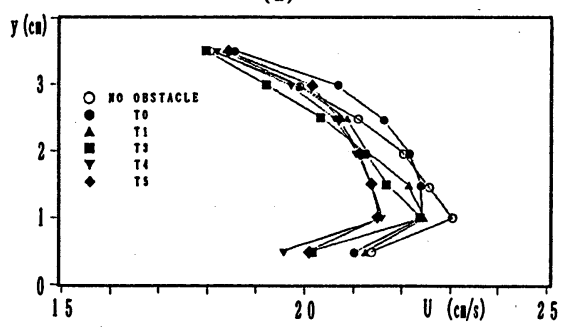

(b)

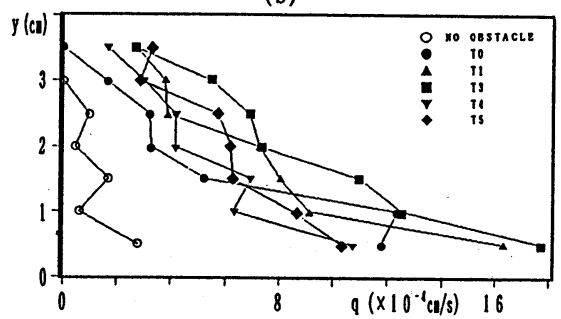

(c)

図一 6 堰頂部におけるC, U, q（RUN4）

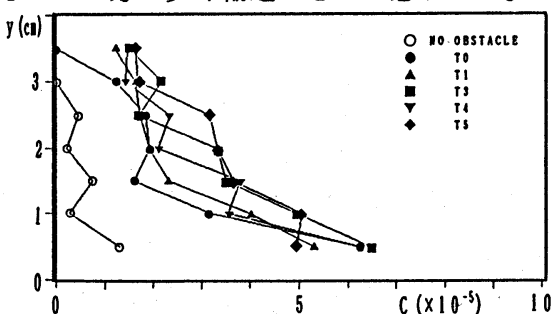

(a)

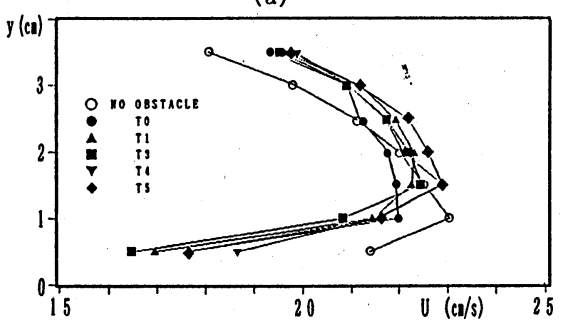

(b)

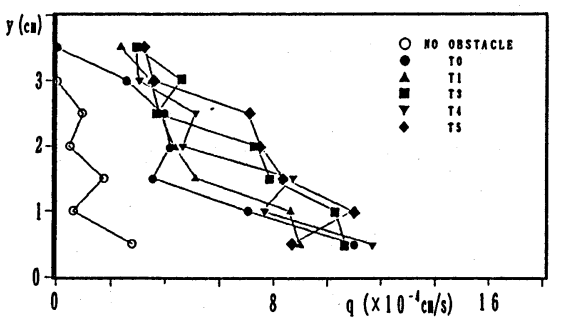

(c)

図一 7 堰頂部におけるC, U, q（RUN5）

図ー8 (a)，(b)はRUN4，RUN5における浮遊砂の輸送量を実際にサイフォンにより抜き取ってその総量を示し たものである。但し、RUN4の場合は通水後0３0分（T03と呼ぶ）と通水後40７0分後（T47）をひとまとまり として、RUN5の場合は通水後0 30分（T03）と通水後50８0分後（T58）をひとまとまりとして抜き取った。 抜き取った位置は、中央断面（L1）と中央断面から物体の直径分だけ側方の断面（L2）において、堰から $0.5,1.5,2.5 \mathrm{~cm}$ の高さの点である（堰頂部における水深は $4 \mathrm{~cm}$ ）。

図ー8 (a)，(b)からすぐにわかることは、RUN4, RUN5とも浮遊砂量は墌に一番近い点において多く、高さが 変化するにしたがって激減していることである。また、RUN4の場合はT03の方がT47よりもL1,L2とも多い。こ れは図ー6，7 の実験において示したようにT47の場合はほぼ定常になっているからである。それに対して、 RUN5の場合はT03よりあT58の方が浮遊砂量が多い。これは、時間が経過するにしたがって河床形状が変化し、 第 1 波背後からの浮遊砂の発生があるためと思われる。また、同じT03を比較すると、RUN4の方がRUN5よりも 浮遊砂量が多い。これは、RUN5の場合には、物体近傍で巻き上げられた浮遊砂のうちの半分くらいが流下す るにしたがって沈降してしまうためと思われる。また、L1,L2を比較すると場合によってはL2の方が多い場合 ああるが、これは物体を回り込む馬蹄形渦により運ばれている成分で、特に堰に近い高さの点でその傾向が 見られる。また、RUN4, 5 とも浮遊砂量qの值は、図ー6、7 の值とほぼ同じとなる。 


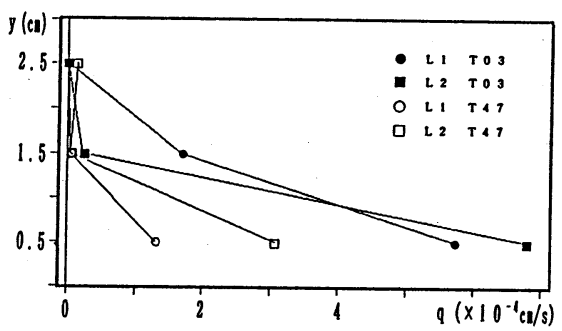

(a)

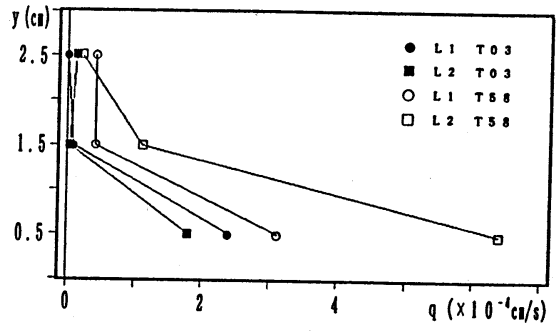

(b)

図-8 堰頂部における浮遊砂量q（サイフォン）（(a)RUN4, (b)RUN5）

\section{5. 結論}

本研究は、底面上の物体背後に生じる組織渦が強い上昇流をもっていることに着目し、組織渦を浮遊砂の 巻き上げ促進に利用するための可能性を検討したすのである。すなわち、堰などの横断工作物の設置などに より流砂量が減少した地点において掃流砂を浮遊砂に変換させて堰を越えさせることを想定したものである。 これにより、以下の諸点が明かとなった。

（1）河床に球を半分ほど沈めた状態で設置すると、その周りに生じる馬蹄型渦や回り込む流机により生じ る 2 次流や物体背後の㔀離渦により、球の周りに激しい洗掘が生じる。洗掘された土砂は球の後方 $4.0 \mathrm{R}$ 位の 位置にほぼ左右対象に堆積する。その堆積高さは球の半径の0.3倍程度で、その下流例にはその堆積形状が引 金となり、第 2 、第 3 の河床波が作られる。河床波の背後からは剝離渦の放出にともなって砂が巻上がるの が確認され、浮遊砂促進という観点からは、非定常時における局所洗掘に上る浮避砂の輸送のほか、河床形 状がほぼ定常に達した後も、物体による上昇流が、掃流砂を浮遊仯に変換する役目を充分に果たするのであ ることが確認された。

（2）球を設置した中央断面において流速分布、濃度分布、浮遊砂分布の流下方向に対する変化を計测した ところ物体がない場合に比べて、濃度分布の重心が上方にずれるのが確認された。この重心のずれは、河床 波が形成される20.0R付近まで続いており、堰前方における砂粒子が堰を越える限界高さとの関連で、殹の前 面の適切な位置に物体を設置することにより堰を越える砂の量を增加させる効果のあることが期待できる。 （３）堰前面部に球を設置して堰頂部における浮遊砂量を測定したところ、場所や時間による浮遊砂量の相 違点が明かとなった。設置位置に関しては現象の起こる時間的なスケールの差や河床形状の差が確認され、 いずれの場合も物体の設置により堰を越える浮遊砂が促進されることが明かとなった。

謝辞 : 東京大学土木工学科玉井信行教授、河原能久講師に御指導頂いた。記して謝意を表します。

\section{参考文献}

1) Jackson, R. G. : Sedimentological and Fluid-Dynamic Implications of the Turbulent Bursting Phenomenon in Geophysical Flows, J.F.M. 77, Part 3, pp. 531 560, 1976.

2) Tamai, N., Asaeda, T. and Tanaka, N.: Vortex Structures around a Hemispheric Hump, Boundary Layer Meteorol.39, pp. 301 314, 1987.

3)吉川秀夫、福岡捷二、岩間汎、曾小川久貝 : 橋脚の洗掘ならびにその防止に関する考察、土木学会論文報 告集、第194号、pp. 83 90, 1971.

4) 関根正人、吉川秀夫 : 砂漣上の浮流砂に関する実験的研究、土木学会論文報告集、第 387 号、pp. 95 103. 1987.

5) Ikeda, S. and Asaeda, T. : Sediment Suspension with Rippled Bed, Proc. ASCE, Jour. of Hyd. Div., No. 3, vol. 109, pp. 409 423, 1983. 